\title{
AN ASSESSMENT OF RESEARCH USAGE IN PUBLIC RELATIONS PRACTICE BY UYO-BASED PUBLIC RELATIONS PRACTITIONERS
}

\section{ITA, OYOKUNYI JON, DR INIOBONG NDA \& NJOKU, ADAUGO NKPURUOMA}

Dept of Communication Arts University of Uyo, Nigeria

\begin{abstract}
Research is a creative and systematic work undertaken to increase the stock of knowledge, including knowledge of humans, culture and society, and the use of this stock of knowledge to devise new application for the furtherance of Public relations and its practice. The role of research is essential to any public relations (PR) effort. Until recently, this aspect of public relations practice suffered from what has been described as a lack of measurable outcomes. This study sought to ascertain the extent to which public relations professionals have used research as a tool in their practice. It made use of a quantitative research method involving questionnaire as an instrument for data gathering. The population for this study were public relations practitioners registered under the Nigerian Institute for Public Relations, Akwa Ibom Chapter, however the sample size was drawn from only practitioners based in the state capital. Findings of the study reveals that several challenges were highlighted as factors hindering the usage of research in Public Relations Practice by Uyo-based practitioners. e.g. funding, client's expectation, management ignorance, lack of co-operation from colleagues and other stakeholders, and the time consuming nature of research in itself.

KEYWORDS: Public Relations, Research, Communications and Publics
\end{abstract}

Received: Feb 18, 2021; Accepted: Mar 08, 2021; Published: May 03, 2021; Paper Id.: IJCMSJUN20214

\section{INTRODUCTION}

Research is a creative and systematic work undertaken to increase the stock of knowledge, including knowledge of humans, culture and society, and the use of this stock of knowledge to devise new applications. It is used to establish or confirm facts, reaffirm the results of the previous work, solve new or existing problems, support theorems, or develop new theories. (Wikipedia, 2019)

The role of research is essential to any public relations (PR) effort. Until recently, this aspect of public relations practice suffered from what has been described as a lack of measurable outcomes. (Stacks, Men, and Dodd, 2011) However, PR practitioners in the world over have come to understand its relevance to the effectiveness of their work.

Public Relations Research can help to define not only what we know, but also what we do not know in any given organizational image issue. This therefore explains why the Institute for Public Relations (IPR) supports public relations research, and makes this knowledge widely available to practitioners, educators, researchers and the customers they assist. Before any PR programme can be undertaken, information must be gathered and interpreted to facilitate the mapping out of effective communication programs. Research is seen as an integral part of the PR process. It is the basis upon which one can develop and evaluate a PR campaign. 


\section{Statement of the Problem}

The practice of public relations has undergone major transformation especially in the last ten years. Along with technological changes, Macnamara (2017) believes that one of the major revolutions has been the demand for accountability and by extension the adoption of the various measures to monitor results such as: Quality Assurance, Quality Accreditation, Customer Satisfaction ratings. This led to the growing employment of research as a major tool in PR practice.

However it is uncertain if the progress made in research in public relations practice across the globe has been imbibed and internalized by PR practitioner based in Uyo, Akwa Ibom state. It is for this reason that this study seeks to ascertain the extent to which public relations professionals have used research as a tool in their practice.

\section{Research Questions}

This research intends to answer the following research questions:

- What is the frequency to which Uyo-based PR practitioners use research in their professional practice.?

- What are the dominant public relations research methods used by Uyo-based public relations practitioners.?

- To what extent does research assist PR practitioners in the attainment of effective PR practice?

- What are the challenges faced by PR practitioners in Uyo in using research in their professional practice.?

\section{LITERATURE REVIEW}

\section{Public Relations and Public Relations Research: A Symbiosis}

Public relations often mean many things to many people. From the ambiguous and not too definitive conception held by many to the broad based conceptualization that has given the profession its many names. To some, Public relations refers to the aspect of their budget which cannot be substantiated, while to some it represents their PR staff ability to provide "women of loose virtues" to the top management staff during social gatherings. But in the midst of all these misconceptions is a term and discipline that has well defined boundaries and operations.

Cutlip, Center \& Broom (1994) sees public relations as the "management function that established and maintains mutually beneficial relationship between an organization and its publics on whom its success or failure depends". This definition clearly underlines the fact that public relations is a two - way process between organizations and its identified publics, groups with common interest affected by the acts and policies of an institution or organization.

The British Institute of Public Relations, cited in Seitel (2001) defines public relations as the deliberate, planned and sustained effort to establish and maintained mutual understanding between an organization and its publics". First this definition reveals that public relations is not a haphazard endeavor, but one that is organized in systematic sequence, which is expected to culminate in solutions to identified problems and must be analyzed by systematic research. Secondly, it shows that public relations actions or events are intentional.

It is designed to influence or gain understanding as well as provide information so as to elicit feedback or reaction from the people or groups affected by the activity. Thirdly, it indicates that effective public relations is a continuing process of a series of organized actions, activities, changes or functions expected to bring about a successful end results and communicate a favorable outcome for the organization. 
Stacks, Dodd \& Men (2011) brings in the perspective of the public within this discourse that public relations research is no different from any other type of corporate research and should strive to meet several ends. First, it should be driven by the same general organizational research assumptions that drive other organizational areas. Second, public relations research must address achievable and measurable goals.

Third, research has specific uses that should match those goals. Fourth, public relations research should be programmatic rather than one-shot case-by-case instance driven. Finally, public relations departments need to have the budget and resources to carry out this research.

Arising from this perspective, Hocking, Stacks, \& McDermott, (2002). opines that :

public relations research is the controlled, objective, and systematic gathering of data. It seeks to describe, understand, predict, and control phenomena Basic research begins by describing what it is that the public relations action is and what it seeks to do. Once described, the research can then be used to understand the concern or problem and establish a baseline against which the public relations campaign can be measured and evaluated.

\section{Importance of Public Relations Research}

Grunig (1984), Grunig (2001) attest to the necessity and indispensability of research to an effective public relations practice because of the growing need for public relations practitioners to convince management to fund research, or to describe the importance of research as a crucial part of a departmental or project budget. The tendency for most organizational management is to see public relations research not as an investment in the brand building process and overall corporate sustainability of the organization rather as an expense that can be avoided when the need arises.

Thus, Grunig (2006), Grunig and Repper (1992) points out that public relations research makes communication twoway by collecting information from publics rather than one-way which is a simple dissemination of information. Research allows PR practitioners to engage in dialogue with publics, understand their beliefs and values, and work to build understanding on the internal workings and policies of the organization.

Ehling \&Dozier, (1992) asserts that research makes public relations activities more strategic by ensuring that communication is specifically targeted to publics who want, need, or care about the information. Without conducting research, public relations is based on experience or instinct, neither of which play large roles in strategic management. Research prevents organisation from wasting money on communications that are not reaching intended publics or not doing the job that they had been designed to do.

Dozier \& Ehling, (1992) believes that research allows organization to show results, to measure impact, and to refocus their efforts based on numbers. For example, if an initiative is not working with a certain public, the ineffectiveness can be shown statistically, and the communication can be redesigned or eliminated. Thus, organizations can direct funds toward more successful elements of the Public Relations initiative. Without research public relations would not be a true management function. It would not be strategic or a part of executive strategic planning, but would regress to the days of simple press agentry, following hunches and instincts to create publicity.

\section{Types of PublicRelations Researches}

There are eseentially three types of researches that can be conducted in any given PR situation namely : 


\section{Quantitative Research}

Al-Jenaibi, (2014) Broom \& Dozier, (1990) sees the quantitative research in public relations as referring to primary research such as public opinion, studies based on surveys and polling. The purpose of quantitative research is to provide a rich, in-depth understanding of how certain people think or feel about a subject. However, the results cannot be generalized to larger populations. Quantitative research allows public relations practitioners to "discover rather than test" ideas. Dennis and Glen (2006) states that quantitative research allows us to have a before and after snapshot to compare the numbers in each group, therefore allowing us to say how much change was evidenced as a result of public relations' efforts.

Quantitative has the major strength of allowing you to understand who your publics are, where they get their information, how many believe certain viewpoints, and which communications create the strongest resonance with their beliefs. Demographic variables are used to very specifically segment publics. Stacks, (2002) further states that segmenting publics is an everyday occurrence in public relations management. Through their segmentation, public relations managers have an idea of who will support their organization, who will oppose the organization, and what communications messages and values- resonate with each public. After using research to identify these groups, public relations professionals can then build relationships with them in order to conduct informal research, better understand their positions, and help to represent the values and desires of those publics in organizational decision making and policy formation.

Methods of Quantitative Data Collection

- Internet-based surveys

- Telephone surveys

- Mail surveys

- Content analysis (usually of media coverage)

- Comment cards and feedback forms

- Warranty cards (usually demographic information on buyers)

\section{Qualitative Research}

The second major kind of research method normally used in the public relations industry is qualitative research. Qualitative research generates in-depth, "quality" information that allows us to truly understand public opinion, but it is not statistically 'generalizable'.

Qualitative research is enormously valuable because it allows us to truly learn the experience, values, and viewpoints of our publics. It also provides ample quotes to use as evidence or illustration in our strategy documents, and sometimes even results in slogans or fodder for use in public relations' messages.

Yin (1994) asserts that qualitative research is particularly adept at answering questions from public relations practitioners that begin with "How?" or "Why?". This form of research allows the researcher to ask the participants to explain their rationale for decision making, belief systems, and values, thought processes, and so on. It allows researchers to explore complicated topics to understand the meaning behind them and the meanings that participants ascribe to certain concepts. For example, a researcher might ask a participant, "What does the concept of liberty mean to you?" and get a detailed explanation. However, we would expect that explanation may vary among participants. When an organization 
seeks to understand how the public see its corporate image, such study will require more tha $\mathrm{n}$ a fleeting answer. It will demand of the researcher to interrogate that public on their understanding of what the corporate image components are, before asking their perception of it. The following methods of data collection exist in the qualitative research: In-depth interviews, focus groups,case studies and participant observation

\section{Mixed Methods/Triangulation}

Tashakkori and Teddlie (1998) demonstrate clearly that both quantitative and qualitative research have complementary and unique strengths. These two research methodologies should be used in conjunction whenever possible in public relations management so that both publics and issues can be fully understood. Using both of these research methods together is called mixed method research, and scholars generally agree that mixing methods yields the most reliable research results.. It is best to combine as many methods as is feasible to understand important issues. Combining multiple focus groups from various cities with interviews of important leaders and a quantitative survey of publics is an example of mixed method research because it includes both quantitative and qualitative methodology. Stacks (2002); Hickson (2003) asserts using two or more methods of study is sometimes called triangulation, meaning using multiple research methods to triangulate upon the underlying truth of how publics view an issue.

\section{THEORETICAL FRAMEWORK}

\section{The Pyramid Model of PR Research}

The Pyramid model was developed by Lindenmann and explored further by McNamara (2002), Madigan (2016).This model uses different steps or "levels" called Inputs, Outputs and Outcomes. The objective of the pyramid model is to "provide a simple practical overview of applied research for public relation practitioners." Theaker (2008) asserts that this model shows how public relations follow a cognitive, attitudinal and behavioural persuasive pattern, Madigan (2008).

According to Theaker (2008), the Pyramid is designed to be read from the "the ground up". The bottom of the pyramid is a representation of "ground zero of the public relations planning process". Here you can begin to plan to research an idea or message and work towards achieving the "desired outcome".

The Inputs or the first stage is where the formative research begins. Here you can research into what the target audience wants or needs, or how they think and feel, making the audience aware of what is going on, expressing to them the aims of the client by using different forms of media to send out the client's message.

Madigan (2016) points out that the Outputs/Outtakes stage or the process and programme evaluation stage is the second stage of the pyramid which shows the public attitudes and ideas developing on the client's message. It can also help the client see what part of the market has consumed the message, how many understand the message from the client or the number of messages you have seen in the media about the client. This can be done through, focus groups, opinion polls, media monitoring and interviews.

The Outcome Stage/ the functional and organisational evaluation stage. It is where you can see if there has been any behavioural changes, or changes in attitudes from the public on the client's message. This can be seen through doing large scale surveys, creating focus groups and general observation of all data and media outlets . 
The importance of the model to the study is that the model describes the key steps of the communication process with specific PR measurement tools for practitioners to choose when, where and what to use. The model also supports both open and closed system evaluation. Baskin \& Aronoff (1992) explains that closed systems focus on the events and messages planned in a campaign and the effect in the targeted publics.

\section{Pyramid Model of PR Research}

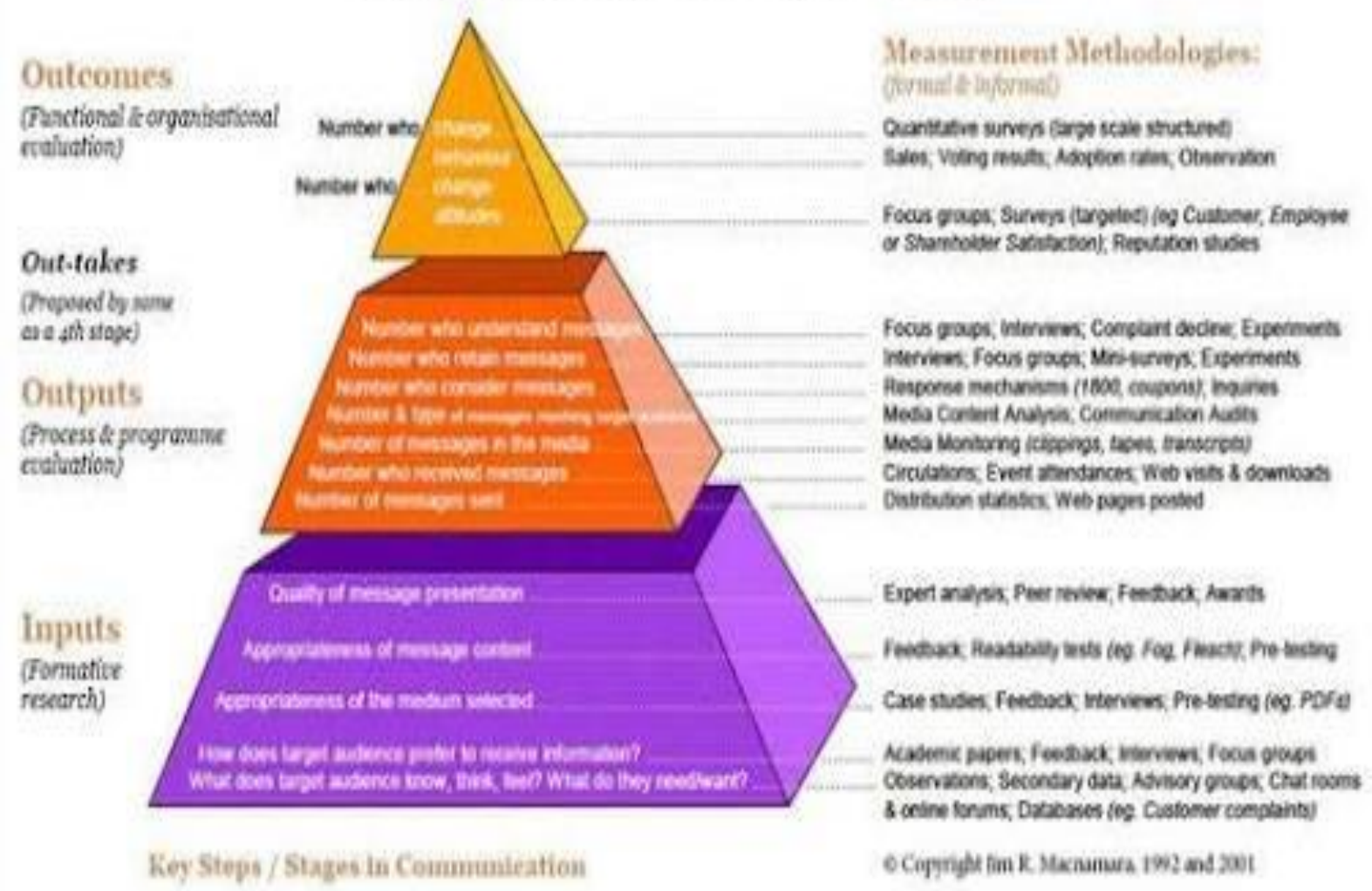

\section{RESEARCH METHODOLOGY}

The study adopted a quantitative research method involving the use of questionnaire as instrument for data gathering. The population of this study consisted of PR practitioners whose names appear in the register of members of NIPR, Akwa Ibom State Chapter as at the time of administering the questionnaire for this study. There are One hundred and Forty (140) registered public relations practitioners in Akwa Ibom State according to the NIPR, Uyo Chapter records last updated April 2019.

The sample size was drawn up from the list of recertified members numbering 65 PR practitioners in all, cut across different strata of operations from government to private consultancy. The study adopted a census sample size utilizing all recertified members. Forty Two copies of the questionnaire was administered through accidental sampling during an NIPR Uyo chapter meeting, while the remaining Twenty three were further administered by mail to the recertified practitioners who were absent from the meeting obtained from the records made available to the researcher by the chairman of the NIPR, Uyo chapter. However, only fifty six copies of the questionnaire were responded to and returned. See distribution of respondents in Figure 1 


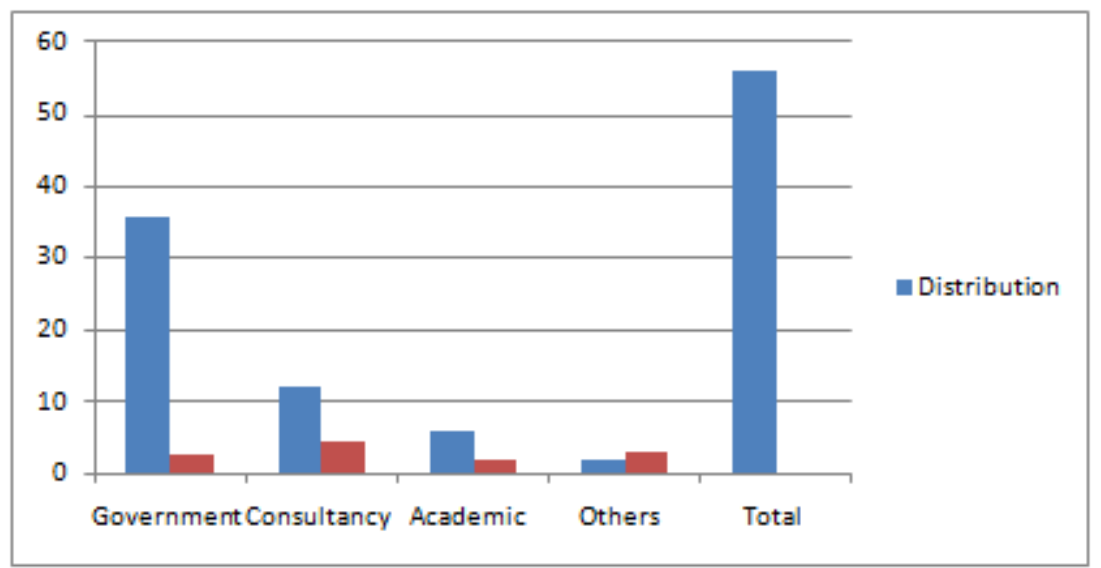

Figure 1: Showing the Distribution Pattern of the Respondent Sample Size

Figure 1 Showing distribution of respondents classification.

All respondents claimed to have management responsibility. Forty-eight (48) i.e. $86 \%$ of the respondents claim to have above 6-10 years of working experience with current organization. and (8)14\% have less than 5years working experience . All of the participants have a Bachelor's Degree with communications background and some with post graduate qualifications.

\section{Findings and Discussion of Findings}

Research Question 1: What is the frequency to which Uyo-based PR practitioners use research in their professional practice.?

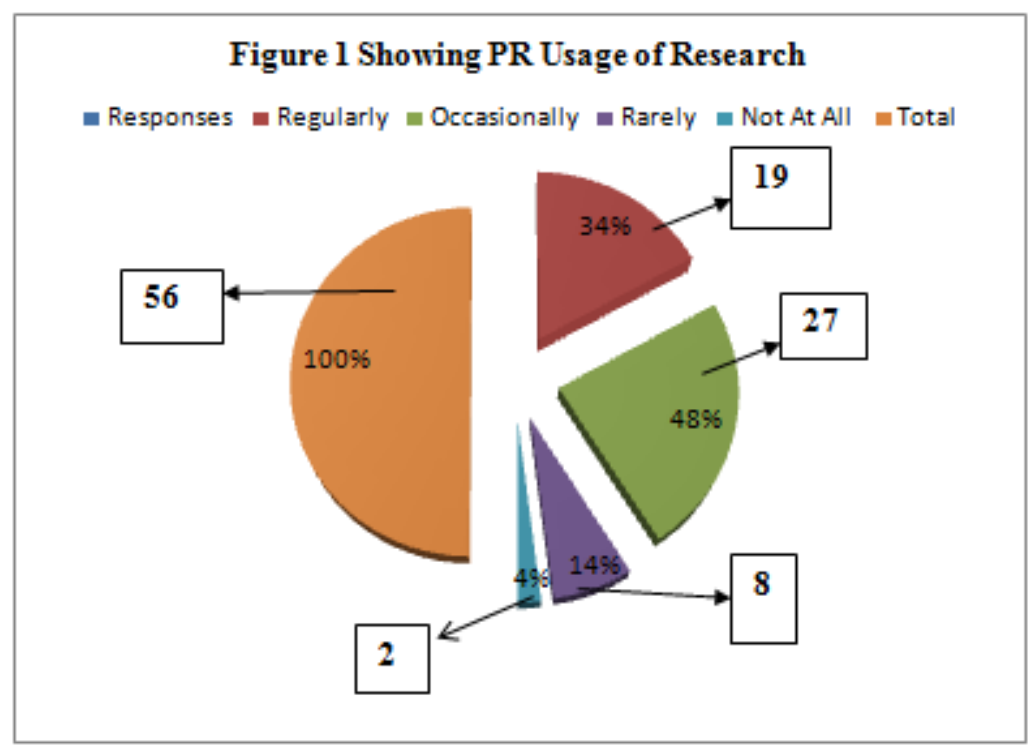

Figure 2: PR Practitioners' Usage Frequency of Research

\section{Field Survey 2019}

Data from the field reflects that Uyo-based PR practitioners reflect that 27 respondents (48\%) acknowledged making use of research occasionally and 19 respondents (34\%) responded that they used research regularly, while only 8 (14\%) and 2 $(4 \%)$ of the respondents stated that they made use of research rarely and not at all agreed to never making use of research. 
The implication of this findings is that the percentage between occasionally and not at all gives a cumulative of $66 \%$ of the respondents who seem to regard research with levity and not as serious as it demands in the publc relations practice.

Ehling \& Dozier (1992) points to the inevitability of research in Public Relations when they assert that research makes public relations activities strategic by ensuring that communication is specifically targeted to publics who want, need, or care about the information. The implication of this finding is that a great deal of public relations in Akwa Ibom state is based on experience or instinct, neither of which play large roles in strategic management.

Research Question 2: What are the dominant public relations research methods used by Uyo-based public relations practitioners.?

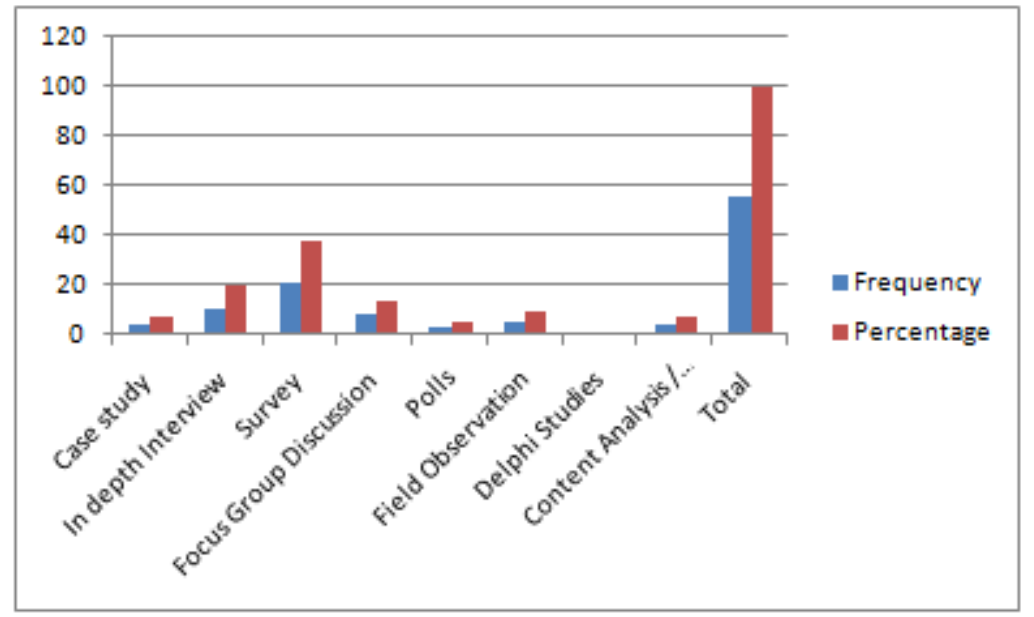

Figure 3: Dominant Research Methods Used by Uyo-Based Public Relations Practitioners

\section{Field Survey 2019}

Data from figure 3 shows that 21 respondents (38\%) of public relations practitioners in Uyo indicated that the survey method was the dominant research methods employed followed by In depth interview and Focus Group. The Content Analysis and Delphi Studies were the least employed research method of them all. The data goes to show that most PR practitioners in Uyo are conversant with the quantitative research methods and qualitative methods but not much of triangulation is employed for better results.

This finding brings to the fore the fact that most PR practitioners are not willing to explore new areas of research methods thus leading to poor diversification of research methods which invariably can lead to serious danger in Public relations trend.

Stacks \& Michaelson (2015) indicts most PR practitioners when they state that many of PR practice is without the adequate knowledge of research thus deprived of the true management function which public relations is known for. Stacks \& Michaelson (2015: 56)

"Without research, public relations would not be a true management function. It would not be strategic or a part of executive strategic planning, but would regress to the days of simple press agentry, following hunches and instinct to create publicity. As a true management function, public relations uses research to identify issues and engage in problem solving, to prevent and manage crises, to make organizations responsive and responsible to their publics, to create better organizational policy, and to build and 
maintain long-term relationships with publics. A thorough knowledge of research methods and extensive analyses of data also allow public relations practitioners a seat in the dominant coalition and a way to illustrate the value and worth of their activities. In this manner, research is the strategic foundation of modern public relations management. (in press)make use of the quantitative research type mostly, this would allow them conduct in-depth research and realise adequate results from doing that."

Research Question 3: To what extent does research assist PR practitioners in the attainment of effective PR practice ?

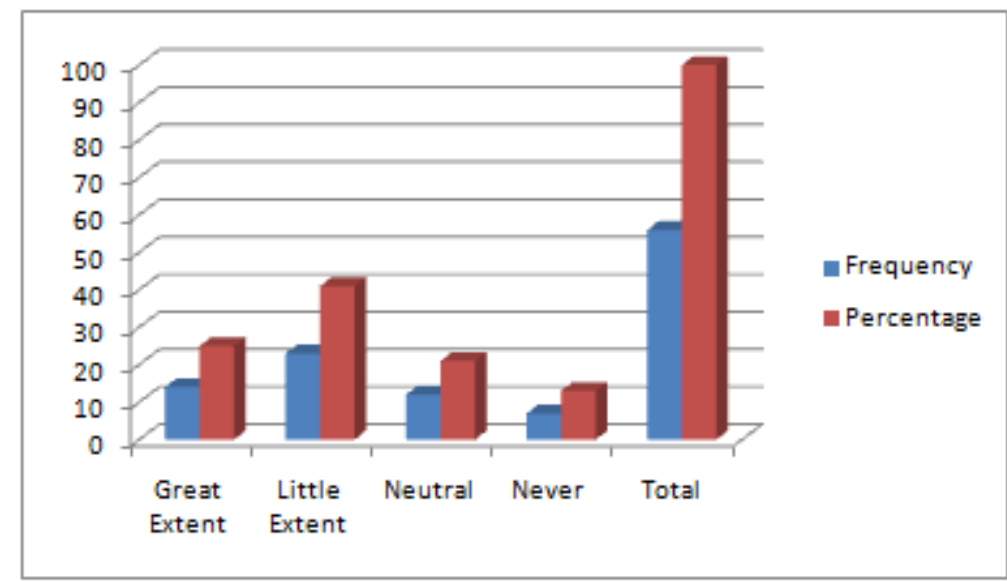

Figure 4: Showing Extent of Research Assistance in Effective PR Practice

Field survey. 2019

Data from Figure 4 reveals 14 respondents (25\%) consider the public relations research as being of great assistance, while 23 respondents (41\%) and another 12 respondents where neutral about the extent of assistance of research in their Public relations practice. Amazingly, 7 respondents (13\%) cant attest to the usefulness research in any form in their practice.

This finding throws up issues that is quite significant to the understanding of the nature of PR practice in the state. In a given situation where research is not considered as a vital tool for survival in the profession it is safe to safe therefore that the profession is on its death route and within a matter of time the "funeral" will be conducted.

Bowen 2009:410) assert that

"we can argue that as much as three quarters of the public relations process is based on research - research, action planning, and evaluation-which are three of the four steps in the strategic management process in the RACE acronym (which stands for research, action planning, communication, and evaluation)."

If practitioners therefore don't consider research as a survival tool rather than a "spare tyre" to be used when the main tyres go bad in the course of practice, then the profession needs a refocus and rethinking for survival.

Auren (2015) buttresses this fact thus it is important to note research is the foundation of all public relations activities and should operate on a continuous cycle. However research is often overlooked and left behind during plan progression. Thus failing to revisit research throughout a plan is a mistake and can lead to expensive repercussions. 
Research Question Four:What are the challenges faced by PR practitioners in Uyo in using research in their professional practice.?

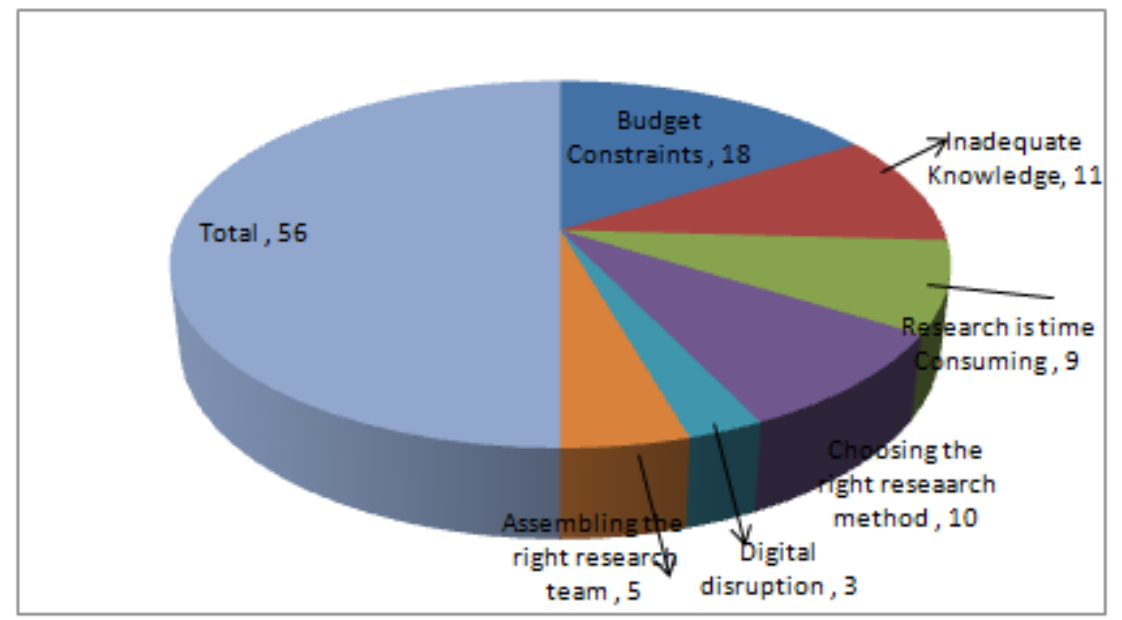

Figure 5: Showing Challenges Faced by PR Practitioners in Research Usage

\section{Field Survey 2019}

Figure 5 reveals the challenges faced by PR practitioners in Uyo using research in their professional practice. The respondents highlighted several reasons as challenges encountered by them in their usage of research in the practice of the profession. 18 respondents representing (32\%) revealed that budget constraints which translate to inadequate funding account for the most challenge they suffer in carrying out PR research. The age of digitalization and digital platforms was considered as the least challenge encountered by practitioners.

This findings corroborate and earlier study by Tom Watson,(1994) as part of post-graduate study in the UK in 1992, found that 75 per cent of PR practitioners spent less than 5 per cent of their total budget on evaluation. He also found that while 76 per cent undertake some form of review, the two main methods used were monitoring (not evaluating) press clippings and "intuition and professional judgment.

Walker (1994) asserts that PR practitioners most commonly cited lack of budget and lack of time as the main reasons for not undertaking research. However, an examination of PR practices and programs suggests that these factors may not be the main obstacles to applying objective evaluation. It was concluded that even if adequate budget and time were available, many practitioners would still not be able to undertaken either evaluative or formative research.

\section{Summary of Findings}

- Uyo-based public relations practitioners make use of research occasionally in their practice of public relations.

- The public relations research method majorly adopted by Uyo-based public relations practitioners is Survey, while Delphi study and content analysis is the least used among them.

- Uyo-based PR practitioners believe that research has not aided them much in their PR practice.

- Several challenges were highlighted as obstructions to the usage of PR by Uyo-based practitioners. E.g. funding, inadequate knowledge of research methods, and assembling the right research team. 


\section{CONCLUSIONS}

It is important to note that the findings of this research points to a worrisome trend, which is that much of PR practice is devoid of research and data infusion. To a great extent the question needs to be asked, without a strong inclusion of Research in the PR practice, how are practitioners able to gauge their communication impact and effectiveness. This trend gives impetus to Pavlik (2009) opinion that public relations practice without research are like mere assumptions about what communication can achieve and will lead to misguided and overly optimistic claim in some public relation plan which makes evaluation risky and problematic.

Thus, much of what PR efforts traditionally have been designed to achieve may be unrealistic without adequate and appropriate research. This research concludes on the note that research is an intricate part of public relations practice that cannot be overlooked and more work still needs to be done to integrate research into the PR professional practice by practitioners in Uyo. These works shouldn't be left to the practitioners alone but all stakeholders and beneficiaries of the PR practice as a whole.

\section{Recommendations}

- $\quad$ PR practitioners need to intensify learning opportunities on how to integrate research into the main stream of PR practice by practitioners.

- Further research needs to be conducted to discover whether with provision of adequate budget and time if, many practitioners would still not be able to undertake either evaluative or formative research.

- Efforts should be put in place by the NIPR and PRCAN to enlighten practitioners as well as clients of the benefits of research to the activities of Public Relations.

- $\quad$ PR practitioners must emphasize the inclusion of research in any PR budget and not as an after thought.

- More work needs to be done to internalize the usage of research as a paramount tool for effect public relations practice.

\section{REFERENCES}

1. Auren, M (2015) Just How Important is Research PublicRelatiowww.skograndpr.com/social media retrieved on $8^{\text {th }}$ August 2020

2. Broom, G., \& Dozier, D. (1990). Using Research In Public Relations: Applications To Program Management. Englewood Cliffs, NJ: Prentice Hall.

3. Ehling, W. P., \& Dozier, D. M. (1992). Public Relations Management And Operations Research. In J. E. Grunig (Ed.), Excellence In Public Relations And Communication Management (Pp. 251-284). Hillsdale, NJ: Lawrence Erlbaum Associates.

4. Gael, W, (1997) 'Public Relations Practitioners' Use Of Research, Measurement And Evaluation' In Australian Journal Of Communication, Vol. 24 (2), 1997, Queensland University Of Technology, P. 101.

5. Grunig, J. E., \& Repper, F. C. (1992). Strategic Management, Publics, And Issues. In J. E. Grunig (Ed.), Excellence In Public Relations And Communication Management (Pp. 117-157). Hillsdale, NJ: Lawrence Erlbaum Associates. 
6. Grunig, L. A., Grunig, J. E., \& Dozier, D. M. (2002). Excellent Public Relations And Effective Organizations: A Study Of Communication Management In Three Countries. Mahwah, NJ: Lawrence Erlbaum Associates.

7. Lindenmann, W. K. (2003). Guidelines For Measuring The Effectiveness Of PR Programs And Activities. Institute For Public Relations. Retrieved August 6, 2020, From Http://Www.Instituteforpr.Org/Research Single/Measuring Activities.

8. Macnamara, J (1996) 'Measuring Public Relations \& Public Affairs', speech to IIR conference, Sydney, .

9. Macnamara, $J \&$ Likely, F , (2017) Revisiting the Disciplinary home of Evaluation: New Perspective to inform PR Evaluation Standards, Research Journal of the Institute for Public Relations Vol 3, No 22017

10. Madigan, J (2017) Practitioner Perspectives on Higher Education as a Preparation for Employment in Public Relations in Ireland, An unpublished Doctoral Thesis submitted to the University of Sheffield.

11. Miles, M. B., \& Huberman, A. M. (1994). Qualitative Data Analysis: An Expanded Sourcebook (2nd Ed.). Thousand Oaks, CA: Sage.

12. Pavlik, J (1987) Public Relations - What Research Tells Us, Sage Publications, p. 68.

13. Stacks, D. W. (2002). Primer Of Public Relations Research. New York: Guilford.

14. Stacks, D. W. (2004). Best Practices In Public Relations Research. Institute for Public Relations. www.instituteforpr.com/bestpractices_ppt_files/v3_document.htm.

15. Stacks, Don W, and Michaelson David; (2010). A Practitioners Guide to Public Relations Research, Measurement, and Evaluation; New York: Business Expert Press, 2010

16. Theaker, A (2008) The Public Relations Handbook, Media Practice, Routledge . 